\title{
Changes in bioclimatic indices \\ in the Republic of Moldova (1960-2012): consequences for tourism
}

Cambios de los índicos bioclimáticos

en la República de Moldavia (1960-2012): consecuencias para el turismo

\author{
Dumitru Mihăilă \\ dumitrum@atlas.usv.ro \\ Department of Geography \\ Ştefan cel Mare University (Romania) \\ Adrian Piticar \\ adrian.piticar@ubbcluj.ro \\ Faculty of Geography \\ Babeș-Bolyai University (Romania)
}

Andrei-Emil Briciu

(corresponding author)

andreibriciu@atlas.usv.ro

Petruţ-lonel Bistricean

petricabistricean@gmail.com

\section{Liliana Gina Lazurca}

lazurca.gina@yahoo.ro

Department of Geography

Ştefan cel Mare University (Romania) 


\title{
Anatolie Puţuntică
}

\author{
aputuntica@gmail.com \\ Department of Geography \\ State University of Tiraspol (Moldova)
}

\begin{abstract}
This study includes a diagnostic and evolutive analysis of the bioclimate of Republic of Moldova, made by using the Wind Chill (WCI) and Cooling Power (CP) indices. The bioclimate of the cold season (October-March) had, in the time period 1960-2012), a warming trend, highlighted by the decrease of $\mathrm{WCI}$ values. During the warm season, the bioclimate of Republic of Moldova recorded a gradual warming, highlighted by the decrease in CP index values. The CP index values were analyzed in relation to those of the Tourism Climate Index (TCI), useful for planning the tourist activities of any kind. The actual values of $\mathrm{TCl}$ and the ones anticipated for the future indicate, for the Republic of Moldova, an increasing bioclimate favorability for all forms and types of tourism.
\end{abstract}

Key words: bioclimate trends; Republic of Moldova; tourist activities.

\section{Resumen}

El presente estudio incluye el análisis diagnóstico y evolutivo del bioclima de la República de Moldavia según Wind Chill Index (WCI) y Cooling Power (CP). Entre 1960 y 2012, el bioclima de la temporada fría (octubre-marzo) presentó una tendencia de calentamiento gradual, evidenciada por la baja de los valores de WCI. Durante la temporada cálida, el bioclima de la República de Moldovia registró un calentamiento gradual, evidenciado por la baja de los valores de CP. Los valores del índice CP han sido analizados según los valores del Índice Climático turístico (TCI), útil para planificar actividades turísticas de cualquier tipo. Los valores actuales de TCl y los anticipados para el futuro indican un clima favorecedor para todo tipo o toda clase de turismo en la República Moldavia.

Palabras clave: tendencias bioclimáticas; República Moldavia; actividades turísticas.

\section{Introduction}

Usage of bioclimate and tourism-climate indices in the analysis of man-climate and tourism-climate relationships is a necessity and also an opportunity, fully applied in the specific scientific researches. During the $20^{\text {th }}$ century, over 100 indices were used for assessing the bioclimate conditions only. (Blazejczyk et al., 2012). The importance of a mixed approach of the meteorological parameters in assessing climate impact on humans was suggested almost a century ago (Buttner, 1938). Bioclimatic indices refer to comfort/discomfort situations, stress conditions and pathology of the 
human body exposure to caloric excess or deficit. Because most people of the world live in urban environment, most bioclimatic studies analyze the built areas (Jaúregui et al., 2002; Nastos \& Matzarakis, 2013; Huang et al., 2015). The scientific studies that analyzed the climate trends by using the bioclimatic indices are not numerous and do not cover all the climatic zones or large territories. In Europe, the climate change implies an increased thermal discomfort (Robine et al., 2008; Schär et al., 2004). The Cooling Power indices were sometimes used in bioclimatic studies (Siple \& Passel, 1945; Tzenkova et al., 2008).

There are few bioclimatic studies that describe the bioclimatic environment in areas close to our study area. For example, Merciu (2010) analyzed the variability of WCI in order to determine the degree of discomfort felt by tourists in the high region of Parâng Mountains, Romania. Teodoreanu and Mihăilă (2012a, 2012b) studied the bioclimatic comfort and discomfort from Suceava Plateau, relying on the monthly, daily and hourly data by using the $\mathrm{WCl}$ and Wind-Chill Equivalent Temperature indices. They made statements on the bioclimatic characteristics and harsh weather, but they have not determined trends of these indices. For the other neighbor country of Moldova (Ukraine), Katerusha and Matzarakis (2015) have analyzed PET and the relationship between the bioclimatic indices and tourism.

The CP index was used in numerous studies, such as those of Ramezani and Palic (2012) and of Farajzadeh and Matzarakis (2012) (the latter also indicated the most favorable period for tourism in the area of Orumieh Lake, Iran).

The WCI and CP bioclimate indices have some disadvantages originated in the inclusion of only two climate parameters in the bioclimate analysis - air temperature and wind speed -, but have the advantage of being computed very easily; they are easily understood not only by specialists, but also by the wide public and have a good temporal applicability and availability for the studied territory.

$\mathrm{TCl}$ is a complex, validated bioclimate index with a great spatial and temporal applicability, fulfilling our objectives. TCl was proposed by Mieczkowski (1985) and it combines seven items/climatic parameters. This index was used by many researchers (Ramezani \& Palic, 2012; Scott et al., 2004) to carry out studies on the implications of climate in tourism. Some studies analyze TCl for areas in the Central and Southern Europe (Amelung \& Viner, 2006; Kovacs \& Unger, 2014).

The climate change affects the touristic potential of all places in the world. Scott et al. (2004) conducted a study for climate-tourism forecast by using the $\mathrm{TCl}$ for the Canadian provinces, until 2050 and 2080, when TCl values indicate better values than the current ones. Also, Scott and McBoyle (2001) explored the impact of designed climate changes on climatic-touristic resources in North America by using $\mathrm{TCl}$. 
Amelung and Viner (2006) studied the impact of climate change on the TCl values of the Mediterranean and other European regions. Hamilton and Tol (2007) discovered that, according to the evolution of $\mathrm{TCl}$ values, in the UK and Ireland the attractive touristic areas will gradually move to north in the near future; also, weather conditions will be more favorable for summer tourism in northern coastal areas of Germany. Overall, $\mathrm{TCl}$ is analyzed for the European continent by Amelung and Moreno (2009) by using data from 1960-1990 and for all seasons; the authors also make projections of the climate-tourism resources for 2020 and 2080, taking 1970 as a reference year.

The few bioclimatic studies about the Republic of Moldova bioclimate represents non-peer review literature which is not published in English. For the Republic of Moldova, there is no study about the selected bioclimatic indices and their trend. To our knowledge, an assessment of the climate favorability for tourism in the Republic of Moldova based on $\mathrm{TCl}$ has not been conducted so far.

The main purpose of this study is to realize the second bioclimatic study of the Republic of Moldova's territory, by including the bioclimatic features from an average year in their inter-monthly evolution based on the bioclimatic indices WCI - analyzed from October to March- and CP analyzed from April to September-, by showing trends of the selected bioclimatic indices for the 1960-2012 period and by estimating bioclimatic forecasts for the 2020 and 2030 time horizons; the WCI-CP relationships are analyzed and CP, a bioclimatic index available for the entire year, is correlated with $\mathrm{TCl}$ in order to indicate the favorability/restrictiveness degree of the climate for tourism in Republic of Moldova.

The future use of PET and radiant mean temperature (Tmrt) indices (Matzarakis et al., 2010) or of weather types (Besancenot-Mounier-Lavenne method, Besancenot et al. (2004), applied in Spain by Gómez (2006) and in Romania by Apostol and Gaceu (2011)) in the diagnosis and forecast analyses of the territory of Republic of Moldova will reveal, through their complexity, new bioclimate and climate-tourism specificities of this country. The use of climate-tourism schemes (CTIS) (Freitas et al., 2008; Lin \& Matzarakis, 2008) could bring a decadal assessment of various climate parameters favorability/unfavorability for tourism in Republic of Moldova. Useful for climate-tourism studies on Republic of Moldova could also be the methods applied by Gómez (2004), Martínez (2011) or Martinez and Gómez (2012). The analysis of the evolution of bioclimate changes in Republic of Moldova can be improved by the thermicity algorithm written by Miró et al. (2016).

The objectives of this study are (1) to analyze the spatial and temporal distribution of $\mathrm{WCI}$ and CP indices during the months of an average year based on the monthly data from the 1960-2012 period, (2) to identify trends of the input parameters of WCI and CP (air temperature, air humidity, wind speed) for the 1960-2012 period and (3) to analyze the current state of tourist activities that depends in various proportions on weather particularities in Republic of Moldova by using the inter- 
monthly evolution $\mathrm{CP}$ and $\mathrm{TCl}$ indices for identifying the most favorable or restrictive periods of the year for tourism.

\section{Material and methods}

\subsection{Study area}

The Republic of Moldova is part of SE Europe, in the NE Balkan Peninsula, having a surface of $33,843.5 \mathrm{~km}^{2}$ (Figure 1). Moldova is a plateau and a hilly plain having an average elevation of 147 m above sea level. In the central part of Moldova lies Codru Plateau -the highest region (Bălăneşti Hill, $429.5 \mathrm{~m}$, the main wooded area of Moldova). The southern part of the country and Nistru River lower plain have the lowest elevation (Nistru valley, 2 m, in the south-eastern part of Moldova). The climate of Moldova is continental temperate and is characterized by annual mean air temperature ranging from $8-9{ }^{\circ} \mathrm{C}$ in $\mathrm{N}$ to $10-11^{\circ} \mathrm{C}$ in $\mathrm{S}$. Annual precipitation values vary between 600 and $650 \mathrm{~mm}$ in the northern and central part and between 500 and $550 \mathrm{~mm}$ in the southern and south-eastern part. The zonal character of the precipitation distribution is substantially modified by the terrain elevation, exposition and slope. The higher amounts are determined both by higher elevations and woody lands. Great variations of the air temperature exist, with frosty winters (when air temperatures fall below $-30^{\circ} \mathrm{C}$; the absolute minimum was $-35.5^{\circ} \mathrm{C}$ at Brătuşeni on January 20 , 1963) and canicular summers (when the absolute maxima reach over $40^{\circ} \mathrm{C}$ in air; the absolute maximum was $42.4{ }^{\circ} \mathrm{C}$ at Făleşti on August 7,2012$)$ and over $70{ }^{\circ} \mathrm{C}$ on soil surface $\left(74{ }^{\circ} \mathrm{C}\right.$ in Leova on July 19, 2007).

The rainfall is also highly variable. During some years, the precipitation oscillated between from under $300 \mathrm{~mm} /$ year to over $900 \mathrm{~mm} /$ year. The highest amount (952 mm) was reached in 2010 at Briceni, while the lowest amount $(208 \mathrm{~mm})$ was recorded in 1928 in Comrat. All climate data were provided by the State Hydrometeorological Service (SHS) of the Republic of Moldova.

According to the National Bureau of Statistics of the Republic of Moldova (2015), this country had a population of 3.55 million people in 2014. Of the total population, 723,500 (20.4\%) were employees. In tourism, between 2002 and 2012, there was an average annual number of only 1,684 employees. In Republic of Moldova, the percentage of tourism in GDP is not included in the official statistics, but it is estimated in various journalistic sources as accounting for only $0.9 \%$ of GDP in 2015. The capacity of tourist reception reached 28,548 seats in 2014 , of which 2,084 seats belonged to health-care structures. The number of tourists staying in all tourist structures climbed in 2014 to 283,001, and 93,897 of them were foreign tourists. In health-care structures 32,920 tourists were accommodated in 2014, of which only 665 were foreigners. The number of overnight stays in the same year reached 1,514,273 (217,930 overnight stays of foreign tourists). In health-care structures, the number of overnight stays was 477,477 , of which 8,329 were the 
overnights of foreign tourists. The main countries providing tourists to Republic of Moldova in 2014 were Romania (22,624 tourists), Ukraine (10,951), Russian Federation $(8,368)$, USA $(6,064)$, Italy $(5,143)$ and Germany $(4,642)$. The accommodation capacity of the receiving structures in 20072014 period was used on an average of $36.6 \%$ (between $17.7 \%$ in hotels and motels and $68.6 \%$ in health-care structures). Tourist balance of Republic of Moldova is asymmetrical; for example, only through travel agencies and tour operators, in 2014, from Republic of Moldova left 180,646 tourists and arrived 14,362 tourists. This country is primarily one emitting tourists and not one of their landing.

Figure 1. Republic of Moldova: location of weather stations

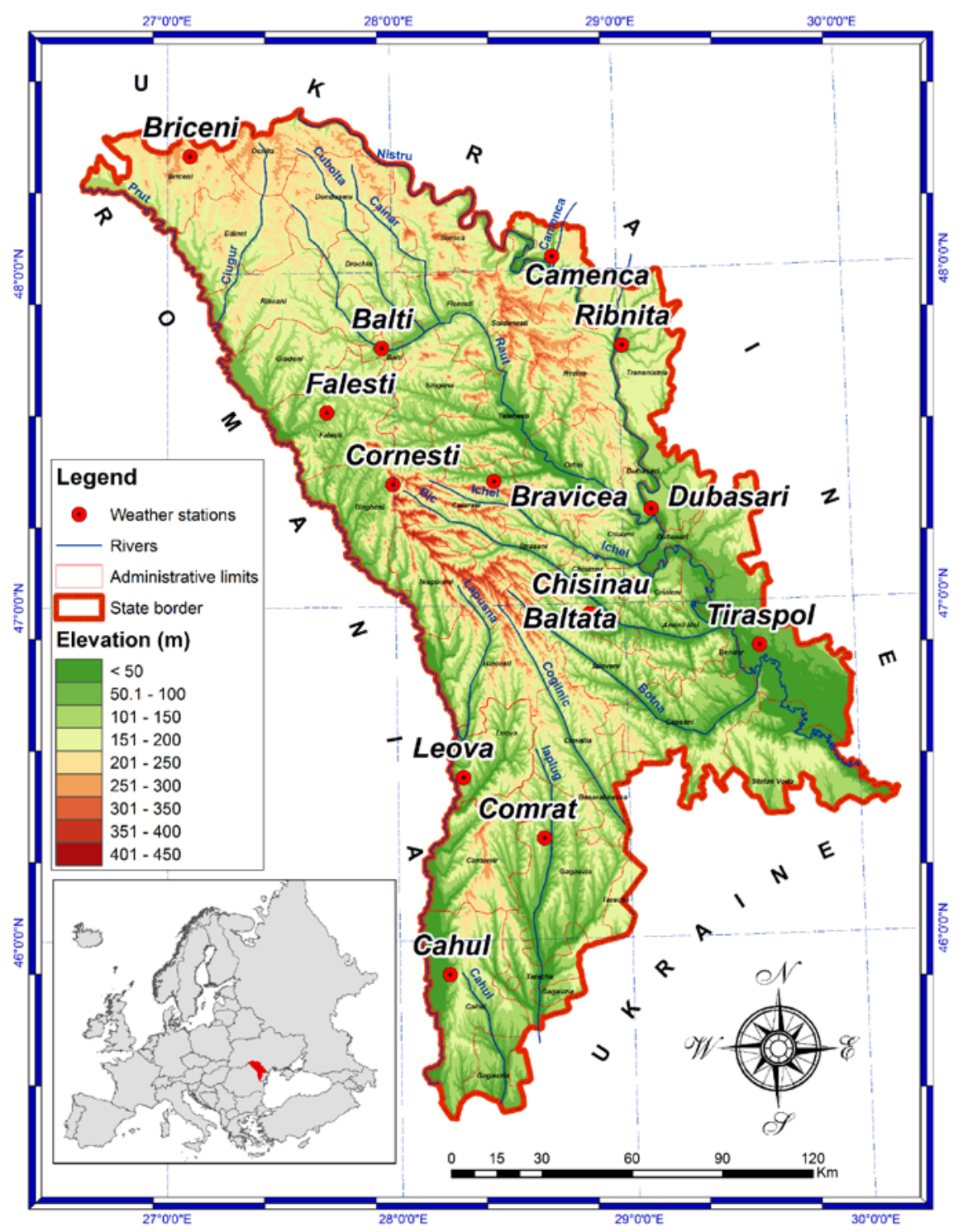

Source: own elaboration

The legislative framework of Moldova (Law no. 352/24.11.2006) identifies tourism as one of the priority areas of the economy. In Republic of Moldova, there are over 15,000 anthropogenic tourist attractions and over 300 important natural areas. The efforts undertaken by the Moldavian 
authorities, according to the tourism development strategy "Tourism 2020", may covert the tourism in the future into a domain that contributes to the economic growth in this country (the strategy anticipates a $3 \%$ annual increment of the number of domestic tourists, a $4 \%$ yearly increase in the number of foreign tourists and a $0.3 \%$ increase of the contribution of tourism to GDP of Moldova within 2014-2020) (GRM, 2014).

Health tourism and other forms of tourism (wine tourism, rural tourism, sport tourism, week-end tourism etc.) may be vectors of tourism development in the future, after the expansion and endowment at new standards of the existing tourist resorts and recreation/treatment facilities (the seaside resort "Nufărul Alb" in Cahul, Codru spa resort in the Hârjauca city, the sanatorium "Bucuria-Sind" in Vadul lui Vodă city, Constructorul sanatorium from Chișinău, the republican center "Speranța" in Vadul lui Vodă city, Struguraș in Cocieri settlement (Transnistria)) are fulfilled.

\subsection{Data}

In the present study, we used air temperature, relative humidity and wind speed monthly data from the 1960-2012 time interval and 13 meteorological stations in the Republic of Moldova (Figure 1, Table 1). Data were provided by SHS. By using the previously mentioned parameters, $\mathrm{WCI}$ and CP were calculated. $\mathrm{WCI}$ and CP indices allow for the bioclimatic analysis of certain intervals of the year. WCI is relevant for revealing the discomfort, stress conditions and pathology of human body exposure to harsh weather (low air temperatures and strong winds) during the cold semester (October 1-March 31) and especially during the winter months (DJF).

Table 1. Geographical coordinates of the weather stations used in this study

\begin{tabular}{|c|c|c|c|c|}
\hline No. & Station name $^{a}$ & Latitude (N) & Longitude (E) & Elevation $(\mathrm{m})$ \\
\hline 1 & Briceni & $48^{\circ} 21^{\prime} 00^{\prime \prime}$ & $27^{\circ} 06^{\prime} 00^{\prime \prime}$ & 258 \\
\hline 2 & Camenca & $48^{\circ} 02^{\prime} 24^{\prime \prime}$ & $28^{\circ} 42^{\prime} 36^{\prime \prime}$ & 39 \\
\hline 3 & Bălţi & $47^{\circ} 46^{\prime} 12^{\prime \prime}$ & $27^{\circ} 56^{\prime} 59^{\prime \prime}$ & 103 \\
\hline 4 & Rîbniţa & $47^{\circ} 46^{\prime} 12^{\prime \prime}$ & $29^{\circ} 00^{\prime} 36^{\prime \prime}$ & 97 \\
\hline 5 & Făleşti & $47^{\circ} 34^{\prime} 48^{\prime \prime}$ & $27^{\circ} 42^{\prime} 00^{\prime \prime}$ & 160 \\
\hline 6 & Corneşti & $47^{\circ} 22^{\prime} 12^{\prime \prime}$ & $27^{\circ} 59^{\prime} 24^{\prime \prime}$ & 234 \\
\hline 7 & Bravicea & $47^{\circ} 22^{\prime} 12^{\prime \prime}$ & $28^{\circ} 26^{\prime} 24^{\prime \prime}$ & 81 \\
\hline 8 & Bălţata & $47^{\circ} 03^{\prime} 36^{\prime \prime}$ & $29^{\circ} 02^{\prime} 23^{\prime \prime}$ & 79 \\
\hline 9 & Chişinău & $46^{\circ} 58^{\prime} 12^{\prime \prime}$ & $28^{\circ} 51^{\prime} 00^{\prime \prime}$ & 172 \\
\hline 10 & Tiraspol & $46^{\circ} 52^{\prime} 12^{\prime \prime}$ & $29^{\circ} 34^{\prime} 48^{\prime \prime}$ & 38 \\
\hline 11 & Leova & $46^{\circ} 29^{\prime} 24^{\prime \prime}$ & $28^{\circ} 16^{\prime} 48^{\prime \prime}$ & 158 \\
\hline 12 & Comrat & $46^{\circ} 18^{\prime} 00^{\prime \prime}$ & $28^{\circ} 37^{\prime} 12^{\prime \prime}$ & 136 \\
\hline 13 & Cahul & $45^{\circ} 54^{\prime} 00^{\prime \prime}$ & $28^{\circ} 12^{\prime} 36^{\prime \prime}$ & 14 \\
\hline
\end{tabular}

Key: ${ }^{a}$ The stations are sorted from $\mathrm{N}$ to $\mathrm{S}$

Source: own elaboration 
The cooling power of the environment (CP) is an index that can be used without restriction in any area of the globe and for the entire year. This index is measured as $\mathrm{Mcal} / \mathrm{cm}^{2} / \mathrm{sec}$, represents the energy losses at the skin surface of the human body and allows us to easily compare it (in this case for the October-March period) with the quantifiable energy losses of the $\mathrm{WCl}$. The values of both indices are maximum in the winter months indicating the biggest caloric losses of the body under a cold and windy atmosphere.

\subsection{Methods}

WCI was calculated in the present study according to the Beçancenot formula (1), created in 1974 by Beçancenot (1974) who updated and simplified the Siple and Passel's WCI formula from 1945:

$$
\mathrm{WCl}=(10 * w+10 \cdot 45-w) *(33-t)
$$

where $\mathrm{WCl}$ is measured in $\mathrm{W} / \mathrm{m}^{2} / \mathrm{h}, \mathrm{w}$ is wind speed in $\mathrm{m} / \mathrm{s}$ and $\mathrm{t}$ is air temperature in ${ }^{\circ} \mathrm{C}$. WCl conveys in a quantitative way the combined air temperature and wind speed effect on the human body caloric balance and represents the intensity of caloric loss (through radiation, conduction, convection, evaporation) in $\mathrm{W}$ per body surface unit area $\left(\mathrm{m}^{2}\right)$ and per time unit (h). lonac and Ciulache (2008) found the effect of the various WCI values on the human body (it depends on the caloric loss intensity. Becker (1972) proposed CP as a mathematical model to identify the human bioclimatic comfort:

$$
C P=\left(0.26+0.34 * w^{0.662}\right) *(36.5-t)
$$

where $\mathrm{w}=$ wind velocity $(\mathrm{m} / \mathrm{s}), t=$ daily average temperature $\left({ }^{\circ} \mathrm{C}\right), \mathrm{CP}=$ cooling power of the environment (Mcal/ $\left.\mathrm{cm}^{2} / \mathrm{sec}\right)$.

In equation (2), one can observe that the cooling power of the environment depends on the difference between human body temperature and air temperature and also on the wind speed. The relationship between the cooling power values and the bioclimatic stimulation thresholds for humans was described by Becker and used with modifications by other authors (Jahanbakhsh, 1998).

Between $\mathrm{WCl}$ and $\mathrm{CP}$ there are very strong correlations for the cold semester of the year that confirms the validity of the used indices (Figure 2). In our approach, after CP is validated by the direct relationship with $\mathrm{WCl}$ for the October-March period, we use this index to analyze the bioclimatic conditions for the warm semester of the year (between April-September). Ultimately, the $\mathrm{CP}$ values are compared for every month of the year with $\mathrm{TCl}$. Because, in Moldova, two periods with distinct bioclimatic characteristics occur each year - the warm one (April-September), with discomfort, stress and pathology caused by the caloric excess from the hot time intervals, and the cold one (October-March), when the medical and bioclimatic phenomena are a result of the caloric deficit, we have chosen to use the selected indices. 
In order to connect the bioclimatic indices during a year (under a multiannual trend outlined clearly enough) to the touristic activities of Republic of Moldova, we used TCl, proposed by Mieczkowski (1985). TCl is calculated by using two complex climate indicators (daytime comfort index (CID), daily comfort index $(\mathrm{CIA})$ ) and three simpler climate indicators (precipitation (P), sunshine $(\mathrm{S})$, wind (W)) (Mieczkowski, 1985).

The TCl formula is:

$$
\mathrm{TCl}=2 *[(4 * \mathrm{CID})+\mathrm{CIA}+(2 * \mathrm{P})+(2 * \mathrm{~S})+\mathrm{W}]
$$

Each indicator receives points from 5 to 0 (5 means that the indicator offers ideal conditions for the practice of tourism and 0 means that it imposes very restrictive conditions). In order to calculate CID and CIA, correlation graphs are drawn on a system of two axes; the horizontal axis corresponds to the maximum daytime temperature and, respectively, to the mean daily air temperature; the vertical axis represents the daily minimum air humidity and, respectively, the daily mean air humidity. The intersection of the axes is represented by the highest temperature values and the lowest humidity values; the index value here is 5 -as the temperature values decrease on the horizontal axis and the humidity values increase on the vertical axis, the index values are reduced towards 0 .

Figure 2. Correlations between WCI-CP for the territory of Republic of Moldova (1960-2012)

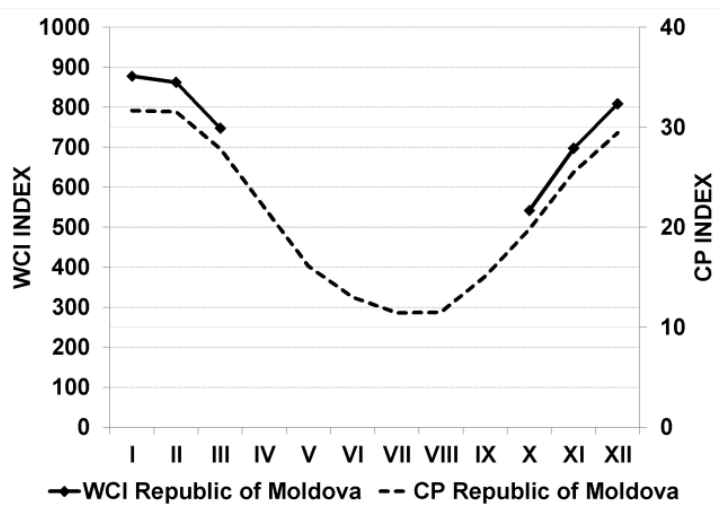

Source: own elaboration

For the months with precipitation between 0 and $14.9 \mathrm{~mm}$, the score given to $\mathrm{P}$ was 5, while for those with precipitation over $150 \mathrm{~mm}$, the given score was 0 . For the months in which the mean daily sunshine duration was $\geq 10$ hours, $S$ received 5 points, while for those when the mean daily sunshine duration was under one hour, the given score was 0 . Concerning $W$, at mean daily wind speed $\leq 0.63 \mathrm{~m} / \mathrm{s}$ it received 5 points, while at mean daily wind speed $\geq 10.7 \mathrm{~m} / \mathrm{s}$ it received 0 points. The impact of various TCl scores on tourism is described by Mieczkowski (1985). Finally, we correlated for all months of the year the mean values of CP with those of $\mathrm{TCl}$ for seven weather stations that uniformly cover the entire Republic of Moldova from north to south. 
In order to determine the bioclimatic indices trend in monthly, seasonal and annual time series we used two methods: a nonparametric method (Mann-Kendall test combined with the Sen's slope test (Sen, 1968)) and a parametric method (linear regression, by using the T-test). These methods have some advantages: missing values are allowed, data does not have to be in conformity to any particular distribution and the Sen's slope is not affected by singular errors in the data row. MAKESENS software (Salmi et al., 2002) was used for two types of statistical analysis: firstly, for testing the presence of a positive or negative monotonous trend by using the Mann-Kendall nonparametric test and, secondly, for calculating the estimated linear trend slope by using Sen's nonparametric method. The Mann-Kendall test was frequently used for studying the bioclimatic indices (Zaninovic et al., 2006; Dobrinescu et al., 2013; Ramezani \& Fallahzadeh, 2014).

The aim and objectives of this study are fulfilled by using in the calculation of bioclimatic indices the monthly averages of the following climatic elements: temperature, humidity, wind. By using them we outline the major bioclimatic characteristics of Republic of Moldova and their trend, detailed on different temporal samples. The study itself does not aim to identify critical or ideal temporal sequences of weather-body relationship, which would have required daily or even hourly data, but this kind of analysis can succeed the current approach. Where the context required (calculation of $\mathrm{TCl}$ ), we used daily values of climate elements (temperature -the average daily maxima and daily average; humidity - the average daily minimum and daily average; rainfall, sunshine, wind speed).

For this study we used the climatic database of the State Hydrometeorological Service of Moldova. The available database allowed us to choose a set of climatic indices that was not used in the bioclimatic studies for Republic of Moldova until now. Because THI (that would have responded well to the aim of this study) was previously analyzed in a recent scientific study (Mihăilă, 2015) and a series of other indices (Humidex, TEE, ISE, ISH, SSI, ITU etc.) have only a very limited spatial and temporal applicability (for some months of the year or for other types of climate), we concluded that the research targets can be achieved by using the WCI and CP indices, which together cover all months of the year, throughout Republic of Moldova and give convincing results.

The spatial distribution of the bioclimatic indices was calculated and mapped in ArcGIS for different time intervals. The average multiannual values of the three bioclimatic indices were interpolated by using the ordinary kriging method. This spatial interpolation method starts from the premise that the values of a variable are autocorrelated on short distances (Patriche, 2009). Other global interpolators, including regression, are not able to remove the anomalies in the spatial distribution of the analyzed climatic element and require a relatively large number of points (stations) to identify a statistically significant relationship. Another disadvantage of the regression consists of "smoothing" the real spatial variation, with modification of the real values from the known points depending on the identified relationship. In contrast to the regression, that integrates altitude, the interpolation by ordinary kriging has the advantage of keeping their own values in the known observations points 
(weather stations) and of reproducing the deviations/"islands" with their real higher or lower values of the analyzed bioclimatic indices.

Consequently, we chose ordinary kriging because it is a suitable interpolation method for the climate elements and phenomena with a higher spatial variability and lower spatial predictability (e.g. the wind speed in the calculation equations depends on atmospheric dynamic). Moreover, the distribution and evolution of the measured meteorological elements (temperature, humidity, wind) in the 13 weather station from Republic of Moldova do intrinsically include the latitude, the dynamic and geographical conditions (altitude etc.) of the monitoring sites

Another problem which requires the use of ordinary kriging instead of other methods is given by the classification in few comfort/discomfort classes of some indices (e.g. CP, for which we can identify only three classes, while during May, June and September the entire Republic of Moldova falls into one class) for which we do not have a more representative spatial variation.

\section{Results}

\subsection{Trends in the primary climatic parameters}

The air temperature, relative humidity and wind speed time series are not affected by the switch from the classical instruments to the automated ones (2004-2008) or by the changes in the geographical coordinates of the weather stations. Transition from manual to automated observations system was done keeping the old monitoring locations and conducting parallel joint observations (classic and automated measurements), the differences between their results during dual observations being insignificant. It was also found that the automatic monitoring system, which gradually took over the duties of observations, has not brought jumps nor substantially modified values in the datasets.

Marin et al. (2014) have analyzed the annual trends in air temperature, wind speed and relative humidity for the territory of Romania (1961-2013) and observed significant temperature increasing trends, significant wind speed and relative humidity decreasing trends for the majority of measuring points.

Before analyzing the trends in the selected bioclimatic indices, we analyzed the trends of the meteorological elements that are included in the selected formulas. We used monthly data of mean, maximum and minimum air temperature, mean relative humidity and mean wind speed. Concerning the air temperature, we noticed that $97.1 \%$ of the analyzed time series showed increasing trends (determined through Mann-Kendall and T tests); $62.9 \%$ have statistically significant increasing trends (Table 2). In the case of thermal maxima and minima, we noticed that the data showed a very high percentage of the increasing trends $(97.1 \%$ for maximum air temperature (MaxT) and $95.7 \%$ for minimum air temperature (MinT)). $65.7 \%$ of MaxT and $51.4 \%$ of MinT have statistically significant 
increasing trends. As far as maximum and minimum air temperatures are concerned, we can confirm that the aerial environment in Moldova was obviously marked by a considerable warming (Nedealcov, 2014).

The relative humidity time series indicate that the atmosphere above Moldova has become drier (82.9\% decreasing trends, $27.1 \%$ statistically significant decreasing trends). A warm and dry atmosphere is not at all benefic for the human body, especially during the warm season when there is a real danger of releasing great concentrations of aerosols caused by the frequent dust storms (Potop \& Soukup, 2009; Parmacli \& Staicova, 2013; Croitoru \& Overcenco, 2013). The studied area is often affected by dust storms because of the Suhovei wind. A strong decreasing trend is also recorded by the wind speed time series. $95.7 \%$ of them show a decay of the wind speed close to the active surface; $82.9 \%$ of all time series show statistically significant decreasing trends.

Table 2. Percentage of trends in the climatic parameters at weather stations in the Republic of Moldova during 1960-2012 (\% /total number of stations; Mann-Kendall test)

\begin{tabular}{|l|c|c|c|c|c|}
\hline & $\begin{array}{c}\text { Total } \\
\text { increasing }\end{array}$ & $\begin{array}{c}\text { Significant } \\
\text { increasing } \\
\text { trend }\end{array}$ & $\begin{array}{c}\text { Total } \\
\text { decreasing } \\
\text { trend }\end{array}$ & $\begin{array}{c}\text { Significant } \\
\text { decreasing } \\
\text { trend }\end{array}$ & $\begin{array}{c}\text { Stationary } \\
\text { trend }\end{array}$ \\
\hline \multicolumn{7}{|l|}{$\begin{array}{l}\text { Primary climatic parameters used for bioclimatic indices calculation } \\
\text { Average air } \\
\text { temperature }\end{array}$} & 97.1 & 62.9 & 0.0 & 0.0 & 2.9 \\
\hline $\begin{array}{l}\text { Relative } \\
\text { humidity }\end{array}$ & 10.0 & 0.0 & 82.9 & 27.1 & 7.1 \\
\hline Wind speed & 2.9 & 0.0 & 95.7 & 82.9 & 1.4 \\
\hline Complementary climatic parameters & 97.1 & 65.7 & 2.9 & 0.0 & 0.0 \\
\hline MaxT & 95.7 & 51.4 & 2.9 & 0.0 & 1.4 \\
\hline MinT & 95 &
\end{tabular}

Source: own elaboration

\subsection{Spatial distribution and temporal evolution of $\mathrm{WCl}$ in the cold semester (October- March)}

This period of the year was chosen for analysis because WCI has a real bioclimatic importance only for this interval of the year (especially for winter, DJF) (Figure 2). During October-January, from one month to another, while the WCI values keep increasing, the thermal discomfort increases; during January-March, the opposite pattern is available and the thermal discomfort decreases.

January has the clearest thermal discomfort and risk, as indicated by WCI values between $<800$ and $>960 \mathrm{~W} / \mathrm{m} 2 / \mathrm{h}$. For all cold semester months, we observed the same $\mathrm{WCl}$ areal distribution. The areas with the highest WCI values are the NNE, WSW and central-western ones (Figure 3). There is a continuous zone with high values of this index linking the northern Moldavian Plateau with the Tigheci Rolling Hills (S) and passing through Bălţi Plain and Prut valley. During the cold season, 
these areas have some factors (long and frequent thermal inversions in the bottom part of the valleys) that favor low air temperature and high wind speed values. The lowest $\mathrm{WCI}$ values are specific for the high and woody areas of the Moldavian Plateau, Nistru valley and central Moldova that are characterized by moderate values of air temperature and wind speed. The same case is for the southern Moldavian Plain and lower Nistru valley where, during the cold season, the moderating Black Sea influences can be felt. A small thermal moderation created by the Stânca-Costești Lake also exists, but the low WCl values in the lake area are due to the high Moldavian Plateau barrier function too.

The $\mathrm{WCl}$ trends indicate a clear decrease at the yearly and seasonal levels. This index shows an air warming phenomenon in Moldova. Only for autumn we have noticed that the trends are not clearly decreasing or increasing. The Mann-Kendall test results for winter confirm that all WCl time series are decreasing (93\% have a statistically significant decreasing trend). The winter spatial distribution of the WCl trends in Moldova shows the spatial dominance of the decreasing trends, even of the statistically significant decreasing trends. Only in the south-eastern part (Tiraspol) and south-western (Cahul) parts of the territory, the winter WCI permanently has an inconstant behavior (Figure 3).

Figure 3. Spatial distribution and trends of WCl index according to the Mann-Kendall test at the meteorological stations from the Republic of Moldova (1960-2012)

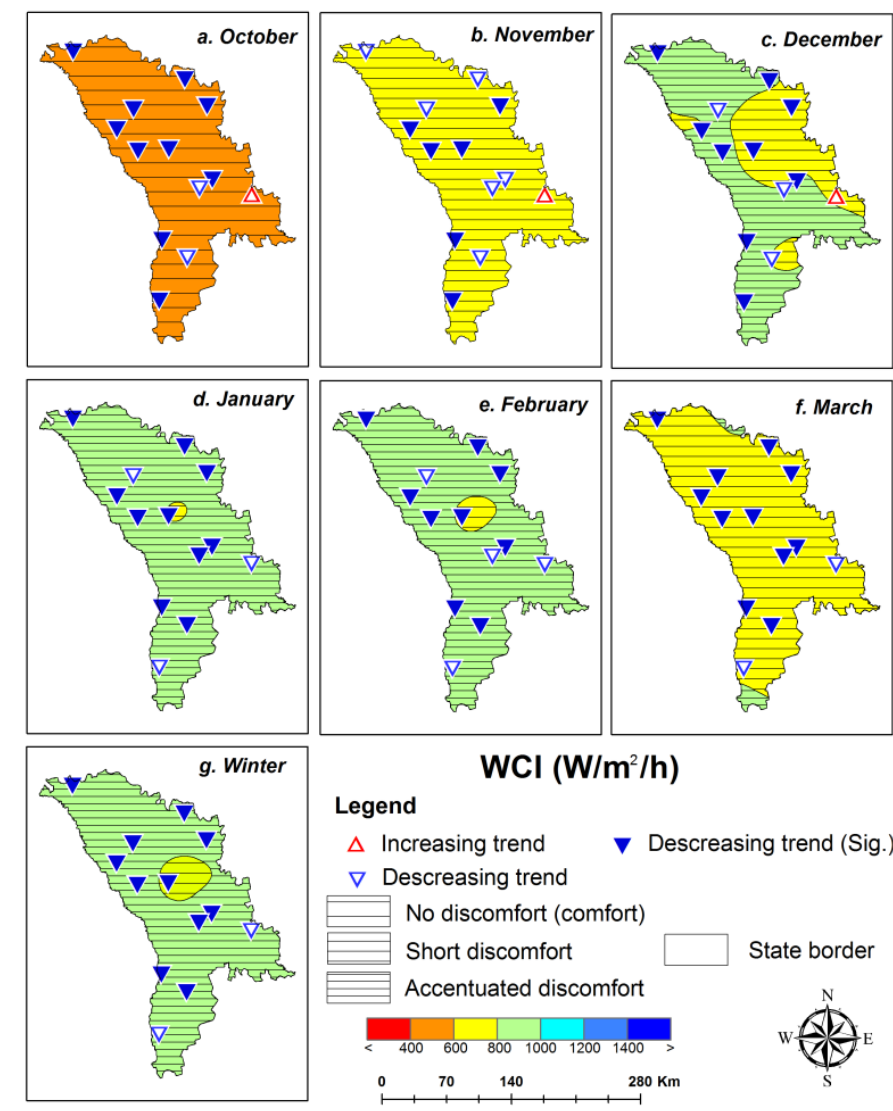

Source: own elaboration 
The evolution of $\mathrm{WCl}$ during October-March indicate a continuous and statistically significant decreasing trends in the central and western part of Moldova. The other territories alternatively record the same behavior or less significant trends of various signs.

Mann-Kendall and T tests indicate that, during October-March, the positive WCI trend occur, but is not statistically significant (Figure 4a, 4b). November has the highest anomalies of this type, with $15 \%$ increasing trends (of all trends in various points of Moldova).

During the entire October-March interval and especially during the winter months, the percentages of the months when $\mathrm{WCl}$ is statistically significant decreasing are high (68-72\% for October-March, $92 \%$ for winter) (Figure 4a, 4b). This fact is a clear sign of warming that occurs in the cold season of the year and is a positive bioclimatic characteristic, taking into consideration that winters are frequently very cold, even frosty, in this part of Europe.

The magnitude of the WCI annual trends during 1960-2012 shows that, in winters, the $\mathrm{WCl}$ index dropped every year by $2.36-2.4 \mathrm{~W} / \mathrm{m}^{2}$. The sum for the 53 years indicates that $\mathrm{WCI}$ dropped by 125.08-127.2 W/m² (Table 3).

During the entire cold semester, the Sen's slope and the slope of the linear regression indicate the decreasing $\mathrm{WCl}$ annual values. January is the month when the decreasing $\mathrm{WCl}$ values are most relevant (between -3.16 and $-3.21 \mathrm{~W} / \mathrm{m}^{2}$ ). The sum for the 53 years shows that $\mathrm{WCl}$ dropped in January by $167.48-170.13 \mathrm{~W} / \mathrm{m}^{2}$.

Figure 4. Percentages of increasing and decreasing trends on different temporal intervals of WCI (Mann-Kendall test - $A$; $\dagger$ test - $b$ ) at the meteorological stations from the Republic of Moldova (1960-2012)

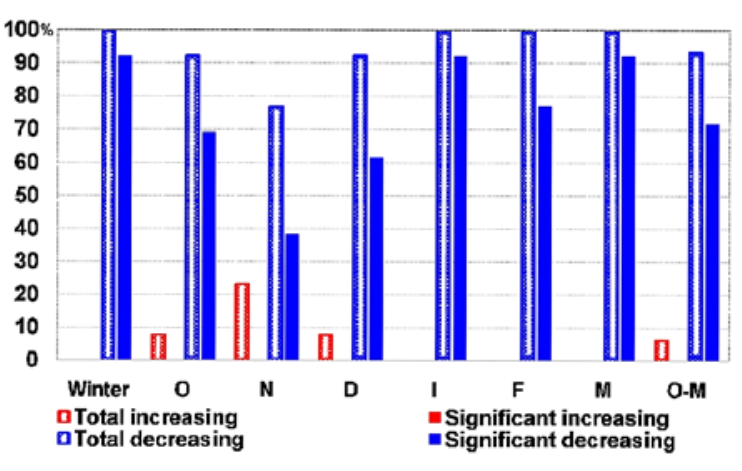

a

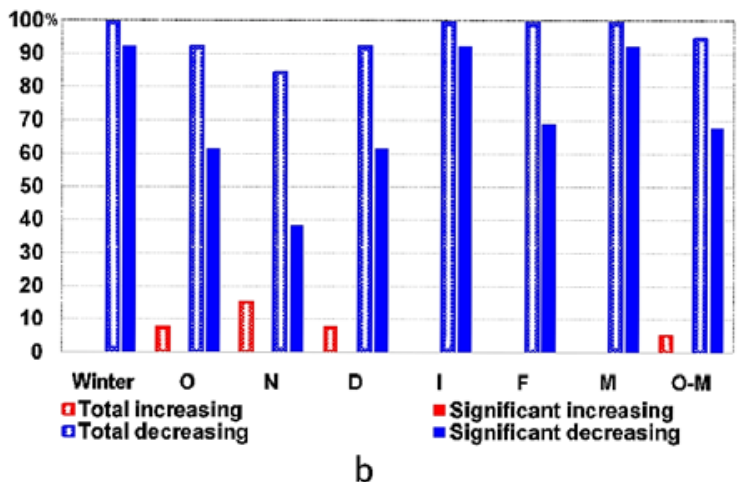

b

Source: own elaboration 
Table 3. WCI ( $\mathrm{w} / \mathrm{m}^{2} /$ year) mean trend slope in the Republic of Moldova (1960-2012)

\begin{tabular}{|l|c|c|c|c|c|c|c|c|}
\cline { 2 - 9 } \multicolumn{1}{c|}{} & Winter & Oct. & Nov. & Dec. & Jan. & Feb. & Mar. & $\begin{array}{l}\text { Oct.- } \\
\text { Mar. }\end{array}$ \\
\hline $\mathrm{WCl}-$ Sen's slope & -2.36 & -1.02 & -0.97 & -1.40 & -3.16 & -2.50 & -2.20 & -1.87 \\
\hline $\mathrm{WCl}-$ linear regression & -2.40 & -0.86 & -0.99 & -1.39 & -3.21 & -2.40 & -2.33 & -1.86 \\
\hline
\end{tabular}

Source: own elaboration

\subsection{Spatial distribution and temporal evolution of the CP index during the warm semester (April-September)}

The spatial distribution of CP for any of the analyzed months (April-September) has north-south or west-east territorial differences which cannot be rendered by the selected cartographic method when using the standard thresholds used by other authors. However, it can be observed that, in April, July and August, in the middle valley of Răut, from Telenești and Orhei districts, the CP values are slightly lower (Figure 4) due to the surrounding forested high hills. A more detailed analysis based on mean monthly CP values reveals that, in winter and spring, it shows a general trend of slight growth (about $3 \mathrm{Mcal} / \mathrm{cm}^{2} / \mathrm{sec}$ in winter and $1.5-2 \mathrm{Mcal} / \mathrm{cm}^{2} / \mathrm{sec}$ in spring). In summer, when the bioclimatic comfort is medium to high, the CP values decrease slightly from north to south (1$\left.1.5 \mathrm{Mcal} / \mathrm{cm}^{2} / \mathrm{sec}\right)$.

In July and August, there are areas where CP values fall below the threshold of 9.9 points, indicating that the atmosphere is warm, but the heat is a tolerable one. In autumn, the comfortable states, followed by the moderate states caused by the gradual cooling of the atmosphere are spatially dominant. Between North and South the CP values grow almost imperceptibly (with 1 $\left.\mathrm{Mcal} / \mathrm{cm}^{2} / \mathrm{sec}\right)$.

From one month to another, the CP differences between distinct weather stations lies within the range of $\sim 10 \mathrm{Mcal} / \mathrm{cm}^{2} / \mathrm{sec}$ in the winter months, while the corresponding value of the summer months is $5 \mathrm{Mcal} / \mathrm{cm} 2 / \mathrm{sec}$ in the summer months (Figure 5). For the whole territory, these differences are lower (being of maximum $5 \mathrm{Mcal} / \mathrm{cm} 2 / \mathrm{sec}$ in the winter and $2 \mathrm{Mcal} / \mathrm{cm}^{2} / \mathrm{sec}$ in the summer) (Figure 6). The maximum values of this index in the winter indicates bioclimatic discomfort by cooling and the minimum values of summer indicate a dominant bioclimatic comfort, interrupted by tolerable heat. The high CP values in the southern part of Moldova in winter is caused by the northern wind (called Crivăț), which blows stronger on a plain topographic surface with almost no barrier.

Calculating the CP trends for the cold semester months we observed that in $96.4 \%$ of the months the CP values are decreasing and only in $3.6 \%$ of cases they are increasing. From the months with decreasing trends of $\mathrm{CP}, 83.3 \%$ have a statistically significant decreasing trend. Therefore, we can state that, in the winter, CP is in a slight decrease. 
Figure 4. Spatial distribution and trends of $\mathrm{CP}$ index according to the Mann-Kendall test at the meteorological stations from the Republic of Moldova (1960-2012)

(the original stations plus Dubăsari weather station)

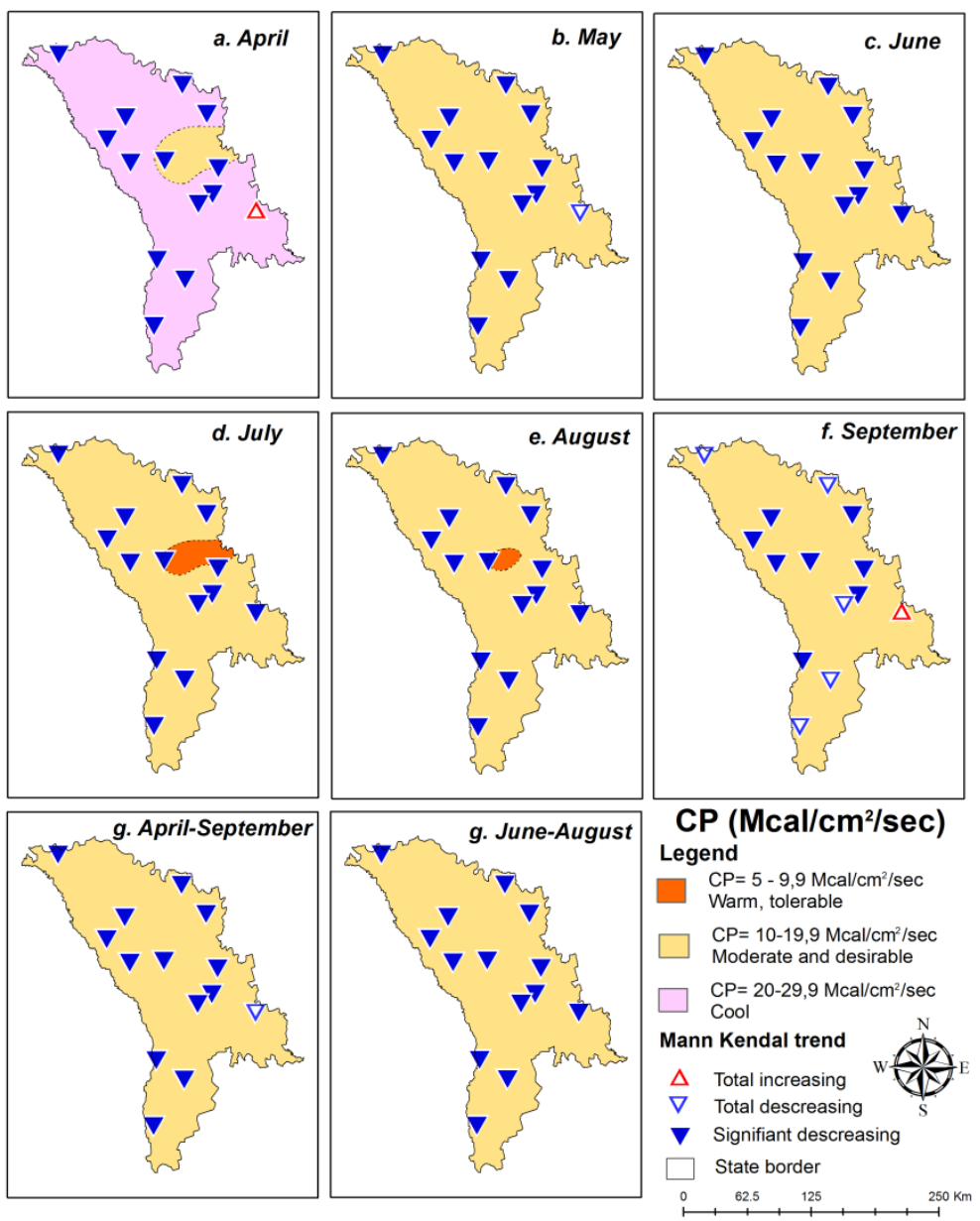

Source: own elaboration

For the months of the warm semester, by using the Mann-Kendall test and the linear regression, we obtained the results shown in Figure 7. July and August are distinct months, with significant decreasing CP trends at all stations. The highest deviation from the mean behavior is recorded in September.

Taking into account the slope of the CP trends (Table 4) we can estimate that, during 1960-2012, the mean monthly values of the analyzed index significantly decreased in July and April (4.3 Mcal $/ \mathrm{cm}^{2} / \mathrm{sec}$, according to the linear regression), while the weakest decreasing trend was in September (only $2.2 \mathrm{Mcal} / \mathrm{cm}^{2} / \mathrm{sec}$ ). 
Figure 5. Annual evolution of CP values (Mcal $\left./ \mathrm{cm}^{2} / \mathrm{sec}\right)$

at the weather stations from Republic of Moldova (1960-2012)

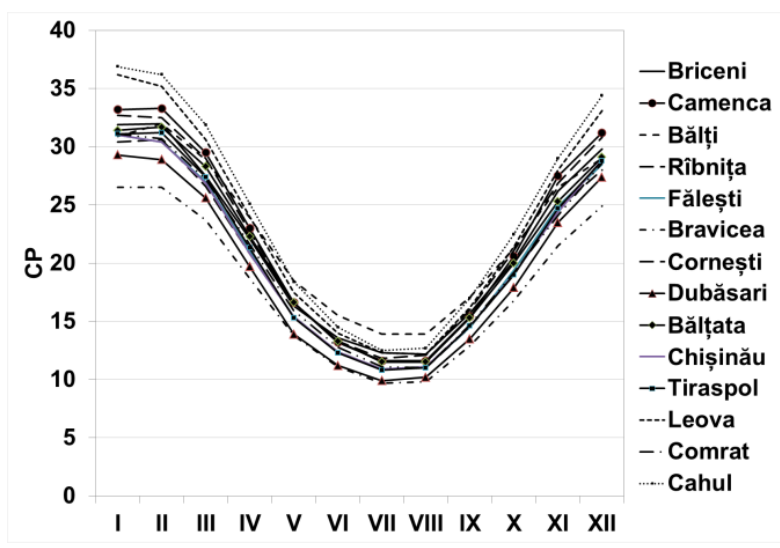

Source: own elaboration

Figure 6. Annual evolution of CP values (Mcal/cm2/sec) in the northern, central and southern third of republic of moldova (1960-2012)

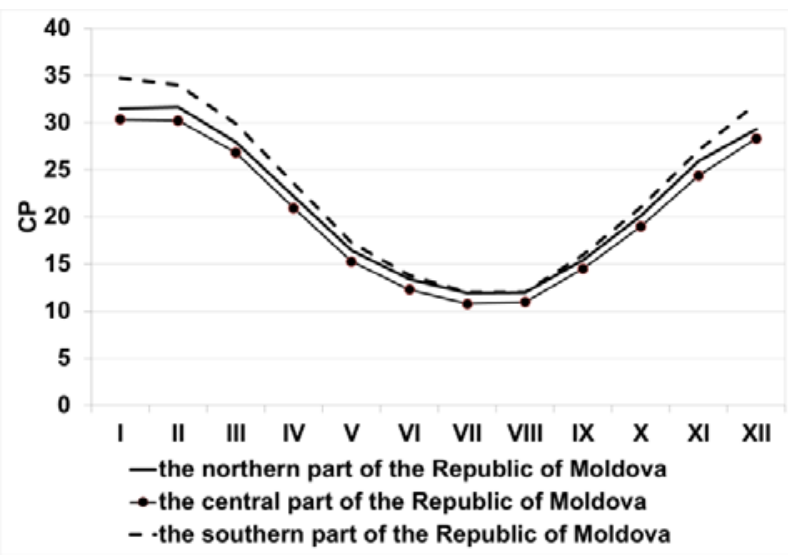

Source: own elaboration

Figure 7. Percentages of increasing and decreasing trends on different temporal intervals of CP (Mann-Kendall test - $a$; $\dagger$ test - b) at the meteorological stations from the Republic of Moldova (1960-2012)

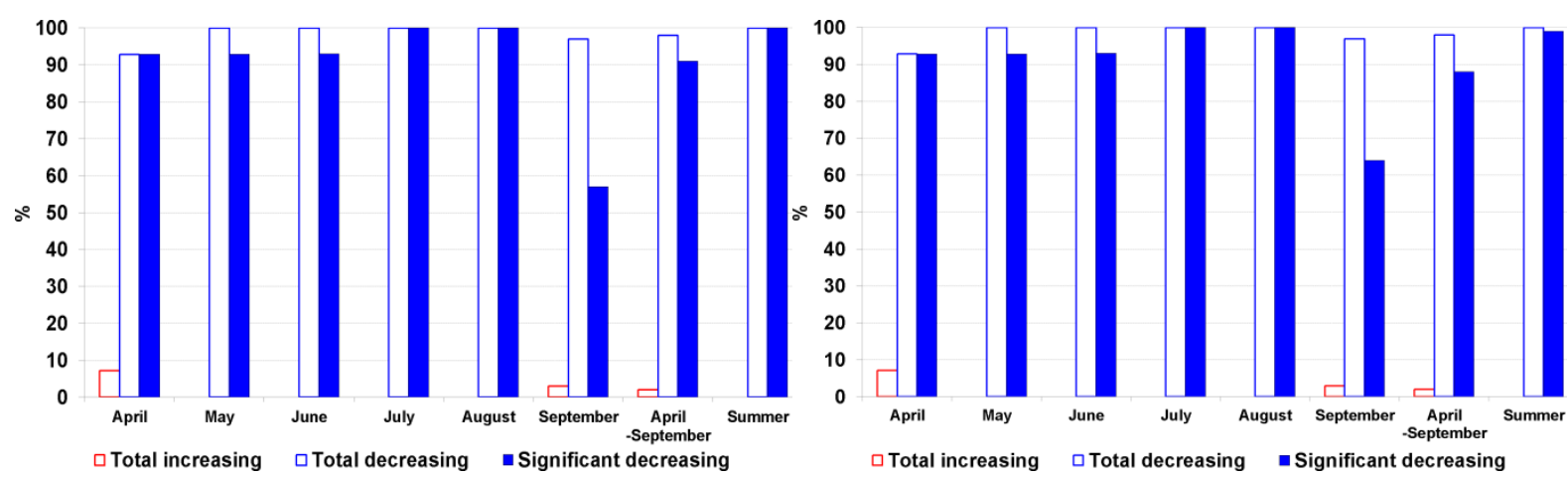

Source: own elaboration 
Table 4. CP (Mcal/cm2/sec) mean trend slope in the Republic of Moldova (1960-2012) and the forecast of the future CP values

\begin{tabular}{|l|c|c|c|c|c|c|}
\cline { 2 - 7 } \multicolumn{1}{c|}{} & April & May & June & July & August & September \\
\hline CP - Sen's slope & -0.09 & -0.08 & -0.07 & -0.09 & -0.07 & -0.05 \\
\hline The magnitude of decreasing & -3.8 & -3.4 & -3.0 & -3.8 & -3.0 & -2.2 \\
\hline CP forecast values for 2020 & 21.3 & 15.8 & 12.7 & 11.0 & 11.3 & 15.0 \\
\hline CP forecast values for 2030 & 20.4 & 15.0 & 12.0 & 10.1 & 10.6 & 14.5 \\
\hline CP - linear regression & -0.1 & -0.09 & -0.07 & -0.1 & -0.09 & -0.05 \\
\hline The magnitude of decreasing & -4.3 & -3.8 & -3.0 & -4.3 & -3.8 & -2.2 \\
\hline CP forecast values for 2020 & 21.2 & 15.7 & 12.7 & 10.9 & 11.2 & 15.0 \\
\hline CP forecast values for 2030 & 20.0 & 14.8 & 12.0 & 9.9 & 10.3 & 14.5 \\
\hline
\end{tabular}

Source: own elaboration

Figure 8. Annual evolution of $\mathrm{CP}$ and $\mathrm{TCl}$ values in different locations from Republic of Moldova (1960-2012)
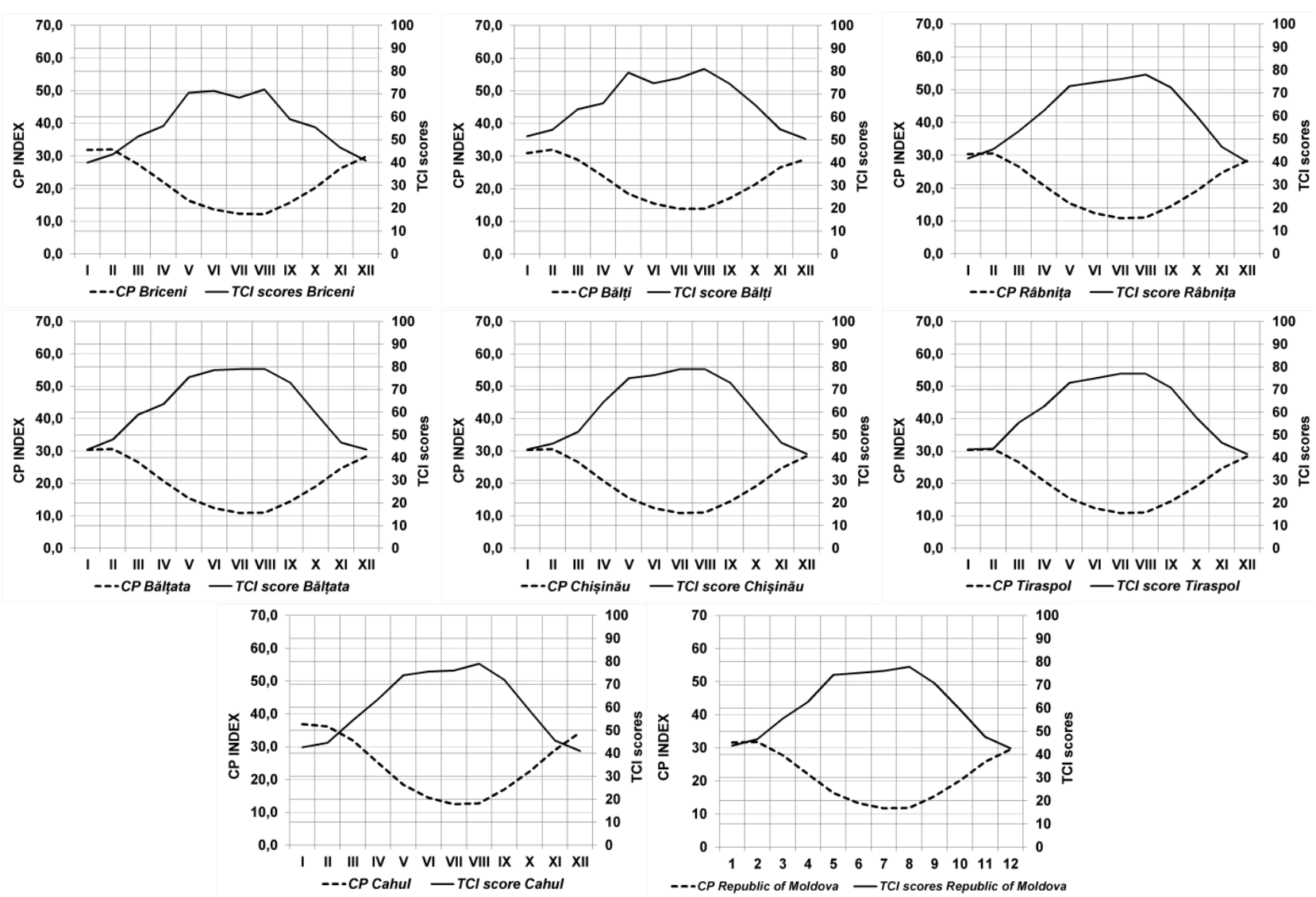

Source: own elaboration

The current trend of $\mathrm{CP}$ in the winter and spring months implies that the bioclimatic conditions will improve gradually. On the other side, the current trend of $C P$ in the summer months will lead to a worsening bioclimate. Decreasing current trends of CP values in the autumn anticipate an improvement of the climate peculiarities for tourism. 
$\mathrm{TCl}$ scores of seven meteorological stations were calculated where all the necessary weather parameters were available. The annual TCI regime, whose development is opposite to that of $\mathrm{CP}$, is shown in Figure 8. The selected stations uniformly cover the studied area.

A summary of the CP and TCl values impact throughout the entire Republic of Moldova is presented in Table 5. We note that from May to September the climate is very good for practicing tourism in this country. In April and October climate provides good conditions for tourism activities in March acceptable, and in the months from November to February less acceptable conditions.

Table 5. Annual evolution of mean monthly values of $\mathrm{CP}$ and $\mathrm{TCl}$ indices and the bioclimatic and touristic consequences in the Republic of Moldova (1960-2012)

\begin{tabular}{|c|c|c|c|c|c|}
\hline Month & $\begin{array}{c}\mathrm{CP} \\
(\mathrm{Mcal} / \\
\left.\mathrm{cm}^{2} / \mathrm{s}\right)\end{array}$ & $\begin{array}{l}\text { Type of bioclimatic } \\
\text { stimulation }\end{array}$ & $\begin{array}{c}\mathrm{TCl} \\
\text { scores }\end{array}$ & $\begin{array}{l}\text { Description of the } \\
\mathrm{TCl} \text { values impact } \\
\text { on touristic activities }\end{array}$ & $\begin{array}{c}\text { Future evolution of the } \\
\text { climate favorability for } \\
\text { tourism }\end{array}$ \\
\hline I & 31.6 & $\begin{array}{l}\text { Moderate and intense } \\
\text { bioclimatic stimulation }\end{array}$ & 43.8 & Less acceptable & Positive evolution \\
\hline$\|$ & 31.8 & $\begin{array}{l}\text { Moderate and intense } \\
\text { bioclimatic stimulation }\end{array}$ & 46.6 & Less acceptable & Positive evolution \\
\hline III & 27.8 & $\begin{array}{c}\text { Moderate } \\
\text { bioclimatic stimulation }\end{array}$ & 55.5 & Acceptable & Positive evolution \\
\hline IV & 22.0 & $\begin{array}{c}\text { Moderate } \\
\text { bioclimatic stimulation }\end{array}$ & 62.7 & Good & Positive evolution \\
\hline V & 16.4 & $\begin{array}{l}\text { Bioclimatic comfort } \\
\text { from medium to high }\end{array}$ & 74.3 & Very good & Positive evolution \\
\hline VI & 13.3 & $\begin{array}{l}\text { Bioclimatic comfort } \\
\text { from medium to high }\end{array}$ & 75.2 & Very good & $\begin{array}{l}\text { Very positive } \\
\text { evolution }\end{array}$ \\
\hline VII & 11.7 & $\begin{array}{l}\text { Bioclimatic comfort } \\
\text { from medium to high }\end{array}$ & 76.1 & Very good & $\begin{array}{c}\text { Very positive } \\
\text { evolution }\end{array}$ \\
\hline VIII & 11.9 & $\begin{array}{l}\text { Bioclimatic comfort } \\
\text { from medium to high }\end{array}$ & 77.9 & Very good & $\begin{array}{c}\text { Very positive } \\
\text { evolution }\end{array}$ \\
\hline IX & 15.4 & $\begin{array}{l}\text { Bioclimatic comfort } \\
\text { from medium to high }\end{array}$ & 70.7 & Very good & Positive evolution \\
\hline$x$ & 20.1 & $\begin{array}{c}\text { Moderate } \\
\text { bioclimatic stimulation }\end{array}$ & 59.5 & Good & Positive evolution \\
\hline$X I$ & 25.8 & $\begin{array}{c}\text { Moderate } \\
\text { bioclimatic stimulation }\end{array}$ & 47.6 & Less acceptable & Positive evolution \\
\hline$X I I$ & 29.5 & $\begin{array}{c}\text { Moderate } \\
\text { bioclimatic stimulation }\end{array}$ & 42.7 & Less acceptable & Positive evolutions \\
\hline
\end{tabular}

Source: own elaboration

The bioclimate trends in 1960-2012 (outlined by the WCI and CP indices) indicates an increase in the climate favorability for health tourism, but also for other types of outdoor tourism activities. The future evolution of the qualitative relationship between climate and tourism was forecasted by us through a quantitative analysis of climate elements trend which was included in the $\mathrm{TCl}$ calculus by using the 1960-2012 time interval (Table 2). One can observe that, for 8 months per year, the tourism activities will be possible in nature/natural environment without too many climate restrictions. 
The annual evolution of weather favorability and climate characteristics influence (together with other factors) the tourist flows in Moldova. The most detailed statistical reporting of tourist flows in Moldova are recorded in the Statistical Yearbook of the Republic of Moldova (NBSRM, 2015) in four quarters of the year: I, II, III and IV.

Figure 9. The annual evolution of: the total number of tourists $(2002-2012$, a); the total number of overnight stays $(2002-2012$, b); the total number of tourists in health-care structures $(2002-2012, c)$; the total number of overnight stays in health-care structures (2002-2012, d), TCI (1960-2012, e) (according to the statistical yearbook of the Republic of Moldova (NBSRN, 2015); letters j-d represent months of the year)

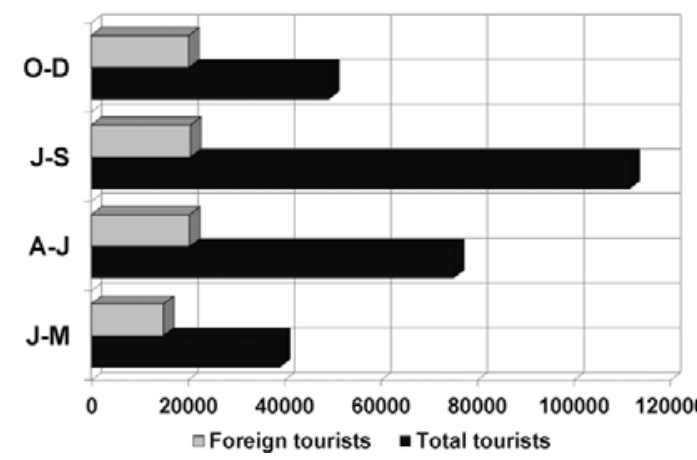

a

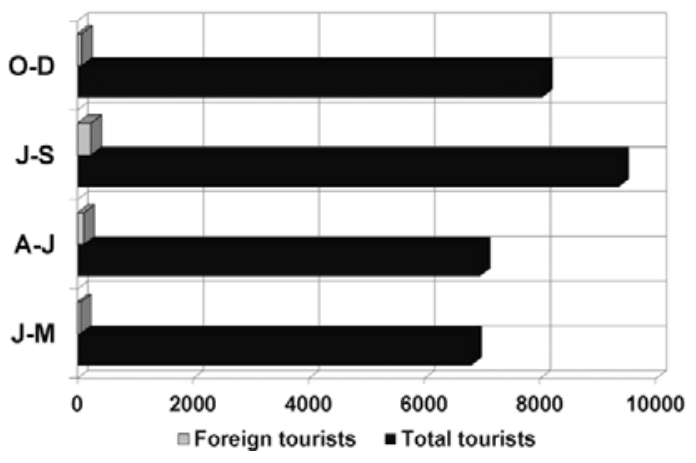

C

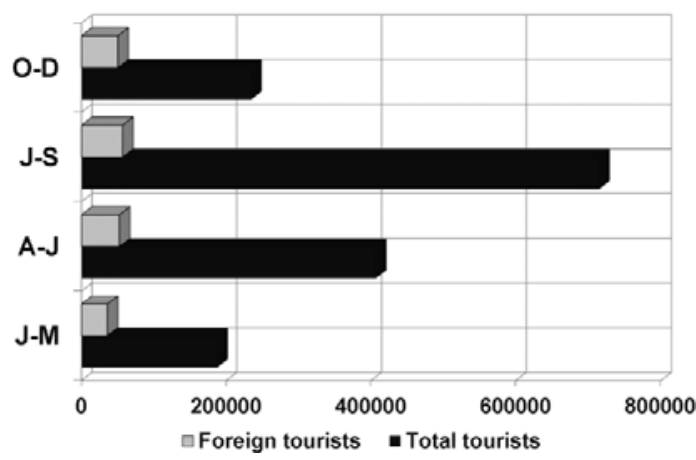

b
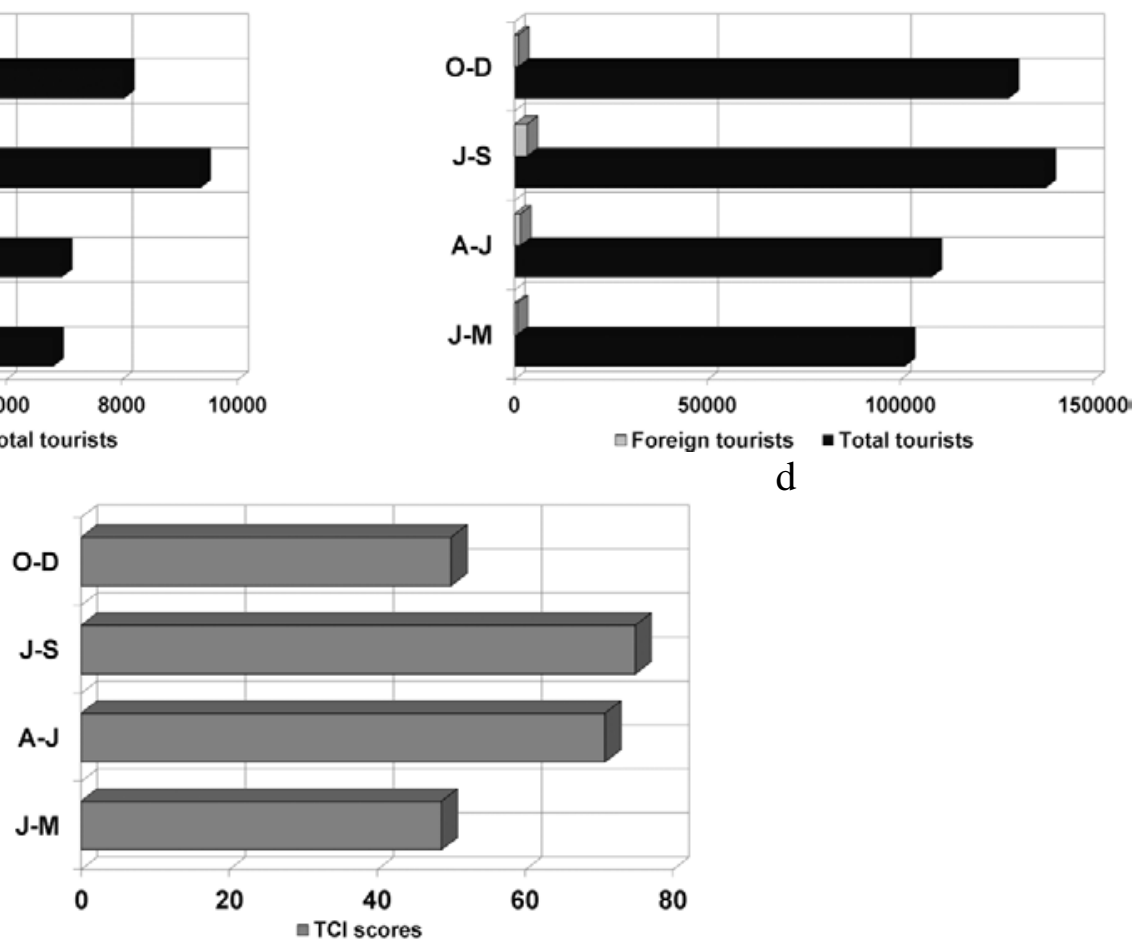

e

Source: own elaboration 
Comparing the average quarterly values of the tourists' number and those of the overnight stays with those of $\mathrm{TCl}$, we can see interdependent links between them (Figure 9): the seasonal tourist flows in an average year is imposed by climatic conditions.

\section{Discussion}

Although in the contemporary society the bioclimatic and climate-tourism analysis is a continuing concern, in the Republic of Moldova this category of analysis did not raised the interest until now. Weather and climate are two pretty important natural factors in choosing a tourist destination (Abegg, 1996). We determined that, in the Republic of Moldova, the average weather condition is favorable for tourism in at least 7 months per year. The tourism industry is particularly sensitive to climate variability (Curtis et al., 2011). Even if the climate variability of Moldova is generally high, between April to October it is attenuated due to the predominance of the anticyclones.

For winter tourism, snow is the main attraction. The Republic of Moldova does not excel in estival or hivernal attractions related to water-sun-beach and, respectively, winter sports, but, with good management, the authorities could develop at a reasonable level these types of tourism. In summer, the climatic resources are favorable for tourism from June until September, while in the winter the favorable period is from December to February. Although the length and quality of the attractive seasons is not ideal, the Republic of Moldova is not the only country facing such problems. Other countries with great touristic vocation have problems in this respect (Scott et al., 2004; Perry, 2001), but take swift action to resolve them.

Maureen et al. (2001) argues that there are powerful climate-tourism conditionings that should be always taken into account by managers and tour operators. For example, in Moldova, the winter touristic traffic is hampered by weather conditions, and in this direction is necessary to make greater efforts. A series of attractions remain blocked in winter or does not fulfill requirements for visitation. In the cities of Republic of Moldova, which have great anthropogenic tourism potential, the winter snow, ice and frost hamper the tourism activity, while, in summer, the heat and pollution often make a suffocating atmosphere.

Republic of Moldova's climatic tourism potential is good and its trend is positive. Forecasts on the climatic-touristic resources made so far have not explicitly targeted the Republic of Moldova, but rather countries or territories with a strongly developed tourism. However, the studies of various authors (Amelung \& Viner, 2006; Amelung \& Moreno, 2009; Sabine et al., 2010) reveal that the climate change will lead to the improvement of the climatic-touristic resources in Central-Eastern Europe. According to the mentioned studies (and our observations in this study, too) within the 2020-2030 timeframe, the unfavorable conditions during winter will persist. In spring and autumn, the changes will be small but positive. During summer, conditions will improve ( $\mathrm{TCl}$ scores will rise). 
Numerous measures can be implemented in order to increase the touristic activity in the summer (extending the official estival time interval or improving the tourism infrastructure). A challenge in this respect will be linked to the quantity and quality of the local water resources, which are already widely used in agriculture during this season.

The forecasted evolution of the regional and local climate will improve the tourist activities in Republic of Moldova (related to sport, culture, relaxation, business, wine, health etc.), especially during summer, but also during spring and autumn; it will extend the duration of the tourist activities, which will improve their parameters and reduce the existing seasonality. By using the forecasted $\mathrm{TCl}$ values, the Republic of Moldova could make some important investments that will improve the tourist infrastructure and offer, having the certainty of obtaining economic benefits on at least the short term. The actual and future planning of tourist activities in Republic of Moldova should take into consideration the forecasted evolution.

\section{Conclusions}

In the case of the average monthly air temperature, $98.9 \%$ of the analyzed time series have increasing trends and $62.6 \%$ have statistically increasing trends. Concerning MaxT and MinT, increasing trends were also recorded (74.2\% of the time series for MaxT and $59.2 \%$ for MinT had statistically significant increasing trends). This evolution is synchronous with the decrease of the wind speed (84.7\% of the time series with statistically significant negative trend) and the decrease of the relative humidity.

For the cold semester of the year and especially during winter, the climate warming is proved by the $\mathrm{WCl}$ decreasing trends. Summed for 53 winters, the $\mathrm{WCl}$ index decreased in Moldova by 126.14 $\mathrm{W} / \mathrm{m}^{2}$. In January (for 53 years, too), the $\mathrm{WCl}$ average decrease was the most relevant (168.8 $\mathrm{W} / \mathrm{m}^{2}$ ). These evolutions represent a demonstration of the climate warming in this part of Europe during the cold season.

The spatial distribution and temporal evolution of $\mathrm{CP}$ and $\mathrm{TCl}$ in the Republic of Moldova indicate that the conditions for the practice of tourism are good and very good from April to October. During the warm semester of the 1960-2012 time interval, the climate recorded a slight warming and it became more dry, less windy and with a sunnier sky, as indicated by the diminishing of CP with values between $4.3 \mathrm{Mcal} / \mathrm{cm} 2 / \mathrm{sec}$ (in July and April) and $2.2 \mathrm{Mcal} / \mathrm{cm}^{2} / \mathrm{sec}$ (in September). Considering the CP estimates for the years 2020 and 2030, we appreciate that the suitability of climate for tourism will grow in the Republic of Moldova. May has the most favorable trends of the climate-tourism relationship, while July and August tend to evolve into excellent conditions for tourism. Months from April to May (corresponding with the spring holiday and Easter) become increasingly favorable, predictable and constant for the tourism practice. From July to August (summer holiday), 
the atmosphere may evolve in 2030 at CP values below $10 \mathrm{Mcal} / \mathrm{cm}^{2} / \mathrm{sec}$, in which case the climate will be a warm, but tolerable one, with a low to medium climatic comfort and with excellent conditions for tourism.

Even if in the actual tourism planning of the Republic of Moldova only the economic, social and political reasons are taken into consideration, the climate forcing should be included as an important factor in the official governmental plans for tourism. Taking into account the evolving climate reality, the Moldovan authorities will be able to complete the existing tourism development strategy ("Tourism 2020" strategy) and that will lead to a better management of this area of activity and to the increase of its viability.

Acknowledgments: The authors acknowledge SHS of the Republic of Moldova for providing the meteorological data.

Authorship statement: The authors declare no conflict of interest. Anatolie Puţuntică contributed with regional data. All authors analyzed the data used for this study. Petruţ-lonel Bistricean made the maps. Dumitru Mihăilă wrote the raw manuscript. Andrei-Emil Briciu has assembled the final manuscript and is the corresponding author. 


\section{References}

Abegg, B. (1996). Klimaänderung und Tourismus. Zürich: Hochschulverlag AG an der ETH.

Amelung, B., \& Moreno, A. (2009). Impacts of climate change in tourism in Europe. PESETATourism study (EUR 24114 EN). Joint Research Centre, Institute for Prospective Technological Studies. doi: 10.2791/3418

Amelung, B., \& Viner, D. (2006). Mediterranean tourism: Exploring the Future with the Tourism Climate Index. Journal of Sustainable Tourism, 14, 349-366.

Apostol, L., \& Gaceu, O., (2011). The climatic-touristic potential of the Romanian Black Sea Coast during summer established according to the method of Besancenot, Mounier and de Lavenne. Carpathian Journal of Earth and Environmental Sciences, 6(1).

Beçancenot, J. P. (1974). Premieres donnes sur les stress bioclimatiques moyens en France. Annales de geographie, 83(459), 497-530.

Becker, F. (1972). Bioklimatische Reizstufen für eine Raumbeurteilung zur Erholung, Forschungs. Sitzungsberichte der Akademie für Raumforschung und Landesplanung Hannover, 76, 45-61.

Besancenot, J. P., Mounier J., De Lavenne F. (1978). Les conditions climatique du tourism littoral, une méthode de recherche comprehensive. Norois, 25(99).

Blazejczyk, K., Epstein, Y., Jendritzky, G., Staiger, H., \& Tinz, B. (2012). Comparison of UTCl to selected thermal indices. International Journal of Biometeorology, 56(3), 515-535.

Buttner, K. (1938). Physikalische Bioklimatologie. Probleme und Methoden (Probleme der Kosmische Physik, Bd. XVIII). Leipzig: Akademische Verlagsgesellschaft.

Croitoru, C., \& Overcenco, A. (2013). Extreme temperatures impact on human health in the R. Moldova. In Abstracts of Days of the University of Medicine and Pharmacy of Târgu Mureș. Târgu Mureș.

Curtis, S., Long, P., \& Arrigo, J. (2011). Climate, Weather and Tourism: Issues and Opportunities. In American Meteorological Society, Meeting Summaries. Greenville, North Carolina.

De Freitas, C. R.; Scott, D., \& Mcboyle, G. (2008). A second generation climate index for tourism (CIT): specification and verification. International Journal of biometeorology, 52(5), 399-407.

Dobrinescu, A., Busuioc, A., Bîrsan, M. V., Ştefan, S., \& Orzan, A. (2013). Spatial and temporal variability of the thermal stress index in Romania. In Geophysical Research Abstracts - EGU General Assembly 2013, EGU 2013-11217, vol. 15.

Farajzadeh, H., \& Matzarakis, A. (2012). Evaluation of thermal comfort conditions in Ourmieh Lake, Iran. Theoretical and Applied Climatology, 107, 451-459. 
Gómez-Martín, M. B. (2004). An evaluation of the tourist potential of the climate in Catalonia (Spain): a regional study. Geografiska Annaler: Series A, Physical Geography, 86(3), 249-264.

Gómez-Martín, M. B. (2006). Climate potential and tourist demand in Catalonia (Spain) during the summer season. Climate Research, 32(1), 75-87.

Government of Republic of Moldova (2014). Tourism 2020. Tourism Development Strategy. Retrieved from http: / /lex.justice. $\mathrm{md} /$ index. php?action=view\&view=doc\&lang=1\&id=353037

Hamilton, J. M., \& Tol, R. S. J. (2007). The Impact of Climate Change on Tourism in Germany, the UK and Ireland: a simulation study. Regional Environmental Change, 7, 161-172.

Huang, K. T., Lin, T. P. \& Lien, H. C. (2015). Investigating Thermal Comfort and User Behaviors in Outdoor Spaces: A Seasonal and Spatial Perspective. Advances in Meteorology, 2015. doi: $10.1155 / 2015 / 423508$

Ionac, N. , \& Ciulache, S. (2008). Atlasul bioclimatic al României. Bucharest: Ars Docendi.

Jahanbakhsh, S. (1998). Assessment of human bioclimate in Tabriz and thermal need of buildings. Geograghical Research Quarterly, 48.

Jaúregui, E., Moreno, M. C., \& Tejada, A. (2002). The energy balance of central Barcelona (Spain). In the urban environment. American Meteorological Society, Norfolk, VA .100-102.

Katerusha, O., \& Matzarakis, A. (2015). Thermal bioclimate and climate tourism analysis for Odessa, Black Sea. Geografiska Annaler: Series A, Physical Geography, 97, 671-679.

Kovacs, A., \& Unger, J. (2014). Analysis of tourism climatic conditions in Hungary considering the subjective thermal sensation characteristics of the South-Hungarian residents. Acta Climatologica et Chorologica, 47-48, 77-84.

Lin, T. P., \& Matzarakis, A. (2008). Tourism climate and thermal comfort in Sun Moon Lake, Taiwan. International Journal of Biometeorology, 52(4), 281-290.

Marin, L., Birsan, M. V., Bojariu, R., Dumitrescu, A., Micu, D. M., \& Manea, A. (2014). An overview of annual climatic changes in Romania: Trends in air temperature, precipitation, sunshine hours, cloud cover, relative humidity and wind speed during the 1961-2013 period. Carpathian Journal of Earth and Environmental Sciences, 9(4), 253-258.

Martínez-lbarra, E. (2011). The use of webcam images to determine tourist-climate aptitude: favourable weather types for sun and beach tourism on the Alicante coast (Spain). International Journal of Biometeorology, 55, 373-385.

Martínez-lbarra, E., Belén, M., \& Gómez-Martín M. B. (2012). Weather, climate and tourist behaviour: the beach tourism of the Spanish Mediterranean Coast as a case study. European Journal of Tourism, Hospitality and Recreation, 3, special issue, 77-96. 
Maureen, A. D., \& Jean, P. P. (2001). Climate impacts on the demand for tourism. In Proceedings of the First International Workshop on Climate, Tourism and Recreation, 41-50.

Merciu, G. L. (2010). Analysis of bioclimatic indicators in white dominant area. Case of study the northern sector of the Parâng Mountains. Annals of the University of Craiova, Series Geography, $13,47-54$.

Mieczkowski, Z. (1985). The tourism climatic index: a method of evaluating world climates for tourism. The Canadian Geographer, 29, 220-33.

Mihăilă, D., Briciu, A. E., Bistricean, P., \& Lazurca, L. G. (2015). The analysis of the spatial distribution and temporal trends of THI index in the Republic of Moldova. In SGEM2015 Conference Proceedings, vol. 4, 1105-1112, doi: 10.5593/SGEM2015/B41/S19.142

Miró, J., Estrela, M., Caselles, V., \& Olcina, J. (2016). Fine-scale estimations of bioclimatic change in the Valencia region, Spain. Atmospheric Research, 180, 150-164. doi: 10.1016/j.atmosres. 2016.05.020.

Nastos, P. T., \& Matzarakis, A. (2013). Human Bioclimatic Conditions, Trends, and Variability in the Athens University Campus, Greece. Advances in Meteorology, 2013. doi: 10.1155/2013/976510 National Bureau of Statistics of The Republic of Moldova (2015). Statistical Yearbook of the Republic of Moldova. Chișinău.

Nedealcov, M. (2014). Climate change and anomalies associated in the Republic of Moldova. Present Environment and Sustainable Development, 8(1), 59-68.

Parmacli, D., \& Staicova, T. (2013). Natural hazards and their effects on agricultural development (case of the Republic of Moldova). Journal of the Geographical Institute "Jovan Cvijic", 63(3), 313320. doi: $10.2298 /$ IJGI1303313P

Patriche, C. V. (2009). Metode statistice aplicate în climatologie. Iași. Terra Nostra.

Perry, A. (2001). More heat and drought - Can Mediterranean tourism survive and prosper? In Proceedings of the First International Workshop on Climate, Tourism and Recreation, 35-40.

Potop, V., \& Soukup, J. (2009). Spatiotemporal characteristics of dryness and drought in the Republic of Moldova. Theoretical and Applied Climatolology, 96(3), 305-318.

Ramezani, B., \& Fallahzadeh, M. (2014). Assessment and analysis of thermal comfort based on bioclimatic indices. Case study: Port of Anzal - Iran. Journal of Applied Environmental and Biological Sciences, 4(1), 116-125. 
Ramezani, B. G., \& Palic, M. (2012). Recognition of monthly human bioclimatic comfort with tourism climate index in Ramsar, South-West of Caspian Sea, Iran. AGD Landscape \& Environment, 6(1), 1-14.

Robine, J. M., Cheung, S. L. K., Le Roy, S., Van Oyen, H., Griffiths, C., Michel, J. P., \& Herrmann, F. R. (2008). Death toll exceeded 70,000 in Europe during the summer of 2003. Comptes Rendus, 331(2), 171-178.

Sabine, L., Perch, N., Amelung, B., \& Knutti, R. (2010). Future climate resources for tourism in Europe based on the daily Tourism Climatic Index. Climatic Change, 103, 363-381.

Salmi, T., MäättÇa, A., Anttila, P., Airola, T. R., \& Amnell, T. (2002). Detecting Trends of Annual Values of Atmospheric Pollutants by the Mann-Kendall Test and Sen's Slope Estimates: The Excel Template Application Makesens. Helsinki: Finnish Meteorological Institute.

Schär, C., Vidale, P. L., Lüthi, D., Frei, C., Häberli, C., Liniger, M. A., \& Appenzeller, C. (2004). The role of increasing temperature variability in European summer heatwaves. Nature, 427(6972), 332-336.

Scott, D., \& Mcboyle, G. (2001). Using a 'tourism climate index' to examine the implications of climate change for climate as a tourism resource. In First International Workshop on Climate, Tourism and Recreation, 69-88.

Scott, D., Mcboyle, G., \& Schwartzentruber, M. (2004). Climate Change and the Distribution of Climatic Resources for Tourism in North America. Climate Research, 7, 105-117.

Sen, P. K. (1968). Estimates of the regression coefficient based on Kendall's Tau. Journal of the American Statistical Association, 63(324), 1379-1389.

Siple, P. A., \& Passel, C. F. (1945). Measurements of dry atmospheric cooling in subfreezing air temperatures. Proceedings of the American Philosophical Society, 89, 177-199.

Teodoreanu, E., \& Mihăilă, D. (2012). Is the bioclimate of Suceava Plateau comfortable or uncomfortable? Analysis based on TEE and THI. Present Environment and Sustainable Development, 6(1), 205-217.

Teodoreanu, E., \& Mihăilă, D. (2012). Is the bioclimate of the Suceava Plateau comfortable or uncomfortable? Analysis based on Wind Cooling Power index and Skin and Lung Stress index. Present Environment and Sustainable Development, 6(1), 229-251.

Tzenkova, A. S., Kandjov, I. M., \& Ivancheva, J. N. (2003). Some biometeorological aspects of urban climate in Sofia. In Proceedings of 5th International Conference on Urban Climate, 2, 103106. 
Zaninovic, K., Cegnar, T., \& Matzarakis, A. (2006). Thermal comfort trends and variability in the Croatian and Slovenian mountains. Meteorologische Zeitschrift, 15(2), 243-251. 